\title{
Comparison of acid-neutralizing capacity of commonly antacids in Erbil city
}

\begin{abstract}
Background and objective: Antacids are basic substances that can neutralize hydrochloric acid and reduce gastric acidity. They are over the counter drugs used to treat dyspepsia. The most commonly used antacids are sodium bicarbonate, magnesium hydroxide, aluminum hydroxide, and calcium carbonate. This study aimed to evaluate the effectiveness of antacids that are commonly used in Erbil city by finding their acid-neutralizing capacity.
\end{abstract}

Methods: The method for acid-neutralizing capacity was adapted from pharmacopeia. The samples were prepared by dissolving the antacid in an excess amount of hydrochloric acid, then neutralizing the excess acid with sodium hydroxide solution by doing back titration. The number of milliequivalents that are neutralized by the antacid is the acid-neutralizing capacity of the antacid.

Results: Rennie $®$ chewable tablet showed the highest acid-neutralizing capacity, followed by AntacidAwa and Maalux ${ }^{\circledR}$ plus. The lowest acid-neutralizing capacity was for the suspensions Gaviscon® and Enoxon $®$.

Conclusion: Acid-neutralizing capacity is an easy and quick method to evaluate the efficacy of antacids. Different combinations of salts and concentrations can affect the acid-neutralizing capacity of the antacid. The higher the neutralizing effect of the antacid, the more effective the antacid is.

Keywords: Acid-neutralizing capacity; Antacid; pH; Dyspepsia; Erbil.

\section{Introduction}

Antacids are basic substances that can neutralize hydrochloric acid and reduce gastric acidity. They are over the counter drugs used to treat dyspepsia. ${ }^{1}$ Most commonly used antacids are sodium bicarbonate, magnesium hydroxide, aluminum hydroxide, and calcium carbonate. All antacids contain bases with a net $\mathrm{pH}$ above 7 and buffer. Antacid works based on different mechanisms, including directly neutralizing acidity, increasing the $\mathrm{pH}$, or reversibly reducing or blocking acid secretion by the gastric cell to reduce acidity in the stomach. ${ }^{2}$ The stomach acid (hydrochloric acid) aids the digestion of food by reducing the $\mathrm{pH}$ to less than 3 . Once the food is ingested, the production of this acid will increase. Excessive production of acid may lead to heartburn, dyspepsia, acid reflux, and even peptic ulcer. Antacids are the most commonly used substances for treating heartburn and dyspepsia or acid reflux, despite the presence of more effective drugs. ${ }^{3}$ In general, antacids act by neutralizing stomach acid and increasing gastric $\mathrm{pH}$ to 4 and 4.2. This will also reduce the activity of pepsin resulting in symptomatic relief of pain. Antacids also increase the esophageal sphincter lower tone so reduce the reflux of gastric acid or content to the esophagus. ${ }^{2,4}$ They are weak base substances, commonly hydroxide and carbonate or bicarbonate, which are combined with cations like aluminum, magnesium, sodium, and calcium. Antacids are classified into two main types.

${ }^{1}$ Department of Pharmaceutics, College of Pharmacy, Hawler Medical University, Erbil, I raq.

* Correspondence: jwan.ahmed@hmu.edu.krd 
The first type is systemic (absorbable) antacids that are easily absorbed into the systemic circulation and may lead to alkalosis like antacids that contain sodium ion. ${ }^{5}$ The second type is non-systemic (non-absorbable) antacids that are not absorbed readily and thus do not make significant systemic effects, such as aluminum containing antacids and magnesium containing antacids. ${ }^{5,6}$ The side effect of the antacid depends on the type of the cation. ${ }^{6}$ These over the counter drugs are available in different formulations, either liquid (suspension) or solid (tablet) and are found in pharmacies and markets. ${ }^{7}$ The most commonly used antacids consist of a combination of different salts. Some of them may contain alginic acid, which acts as a barrier and protects the gastric mucosa by the formation of a floating raft, thus preventing acid reflux to the esophagus. Simethicone or dimethicone also may be added to antacid formulation to decrease flatulence. ${ }^{8}$ The efficacy of antacids is determined by their acidneutralizing capacity, which is expressed in milliequivalent $(\mathrm{mEq})$. This is defined as the number of $\mathrm{mEq}$ of $1 \mathrm{~N} \mathrm{HCL}$ that is brought to $\mathrm{pH} 3.5$ in $15 \mathrm{~min}$. Acid-neutralizing capacity varies within different antacid formulations. The ideal antacid should be effective per unit cost, neutralizing the largest volume of the acid, not producing any systemic side effects like alkalosis, and easily used by the patient. ${ }^{9,10}$ The US FDA requires that an antacid must have a neutralizing capacity of $\geq 5 \mathrm{mEq}$ per dose. ${ }^{11}$ In this research, a comparison of acid-neutralizing capacity was made for five different antacids that are commonly used in Erbil city. This study aimed to evaluate the effectiveness of antacids that are commonly used in Erbil city by finding their acid-neutralizing capacity.

\section{Methods}

\section{Materials:}

Hydrochloric acid 37\% (extra pure, PhEur, BP, NF, Scharlau), sodium hydroxide (extra pure, Ph, BN, Scharlau), distilled water,
HANNA instruments $\mathrm{pH}$ meter, Sartorius sensitive balance, magnetic stirrer, glassware. All of them were provided by the College of Pharmacy/ Hawler Medical University. Antacids that were tested are Rennei ${ }^{\circledR}$ tablet, Gaviscon ${ }^{\circledR}$ syrup, Maalux $\AA$ plus, AntacidAwa $\AA$ tablet (Awamedica), and Enoxon ${ }^{\circledR}$ syrup were obtained from the market.

\section{Methods:}

The method for acid-neutralizing capacity was adapted from pharmacopeia. ${ }^{12}$ The samples were prepared by dissolving one dose of antacid in $70 \mathrm{ml}$ of distilled water and mixing by a magnetic stirrer for one minute. Then $30 \mathrm{ml}$ of $1 \mathrm{~N} \mathrm{HCL}$ was added with continuous stirring. The stirring was continued for another 15 minutes. Then the sample was titrated with $0.5 \mathrm{~N} \mathrm{NaOH}$ until a stable $\mathrm{pH}$ of 3.5 was obtained. The tablets were crushed into fine powder by mortar and pistol before dissolving to simulate disintegration. The acidneutralizing capacity was calculated by the following equation: ${ }^{9}$

$$
\mathrm{ANC}=\left(\mathrm{N}_{\mathrm{Hcl}} \times \mathrm{V}_{\mathrm{Hcl}}\right)-\left(\mathrm{N}_{\mathrm{NaOH}} \times \mathrm{V}_{\mathrm{NaOH}}\right)
$$

The test was repeated three times for each brand of antacid, and standard deviation was measured. All the work was carried out in the pharmaceutical laboratory of the College of Pharmacy, Hawler Medical University in Erbil city, from September 2019 to January 2020.

\section{Statistical analysis}

All experiments were performed in triplicates, and values were expressed as mean \pm standard deviation. Statistical significance was assessed using the Kruskal Wallis test with a level of significance of $<0.05$ followed by Tukey's Honestly Significance Difference (HSD) method as a Post-hoc analysis.

\section{Results}

The antacids used had different ingredients, which are shown in Table 1. Acid-neutralizing capacity for all antacids from different brands was found. The test was done in triplicates for each brand then 
https:/ / doi.org/ 10.15218/ zjms.2021.023

the mean and standard deviation formulation is shown in Table 2 and was found. The result for each Figure 1.

Table 1: Contents of antacids used in the test.

\begin{tabular}{|c|c|c|}
\hline Antacids & $\begin{array}{l}\text { Acid-neutralizing } \\
\text { capacity }\end{array}$ & Content \\
\hline AntacidAwa ${ }^{\circledR}$ TAB & 13.5 & $\begin{array}{l}\text { Dried aluminum hydroxide } 200 \mathrm{mg} \text {, magnesium } \\
\text { hydroxide } 200 \mathrm{mg} \text {, simethicone } 25 \mathrm{mg}\end{array}$ \\
\hline Rennie ${ }^{\circledR}$ tablet & 18.05 & $\begin{array}{l}\text { Calcium carbonate } 680 \mathrm{mg} \text {, magnesium } \\
\text { carbonate } 80 \mathrm{mg}\end{array}$ \\
\hline Maalux $®$ plus tablet & 12.5 & $\begin{array}{l}\text { Magnesium hydroxide } 200 \mathrm{mg} \text {, aluminum } \\
\text { hydroxide } 200 \mathrm{mg} \text {, dimethicone }\end{array}$ \\
\hline Enoxon®oral suspension & 5.65 & $\begin{array}{l}\text { Sodium bicarbonate } 267 \mathrm{mg} \text {, sodium alginate } \\
500 \mathrm{mg} \text {, calciumcarbonate } 160 \mathrm{mg}\end{array}$ \\
\hline Gaviscon ${ }^{\circledR}$ oral suspension & 7.25 & $\begin{array}{l}\text { Sodium alginate } 500 \mathrm{mg} \text {, sodium bicarbonate } \\
267 \mathrm{mg} \text {, calcium carbonate } 160 \mathrm{mg}\end{array}$ \\
\hline
\end{tabular}

Table 2: Results for volume of sodium hydroxide neutralized and acid-neutralizing capacity of the different antacids tested showing the standard deviations.

\begin{tabular}{lccc}
\hline Antacids & $\begin{array}{c}\text { Mean volume of } \\
\text { NaOH }\end{array}$ & $\begin{array}{c}\text { Mean acid-neutralizing } \\
\text { capacity }\end{array}$ & SD \\
\hline Rennie $®$ chwable tablet & 23.9 & 18.05 & 1.129 \\
AntacidAwa $®$ TAB & 33 & 13.5 & 1.258 \\
Maalux® plus & 35 & 12.5 & 1.607 \\
Enoxon $\circledast$ oral suspension & 47.8 & 5.65 & 0.546 \\
Gaviscon® oral suspension & 45.5 & 7.25 & 0.433 \\
\hline
\end{tabular}

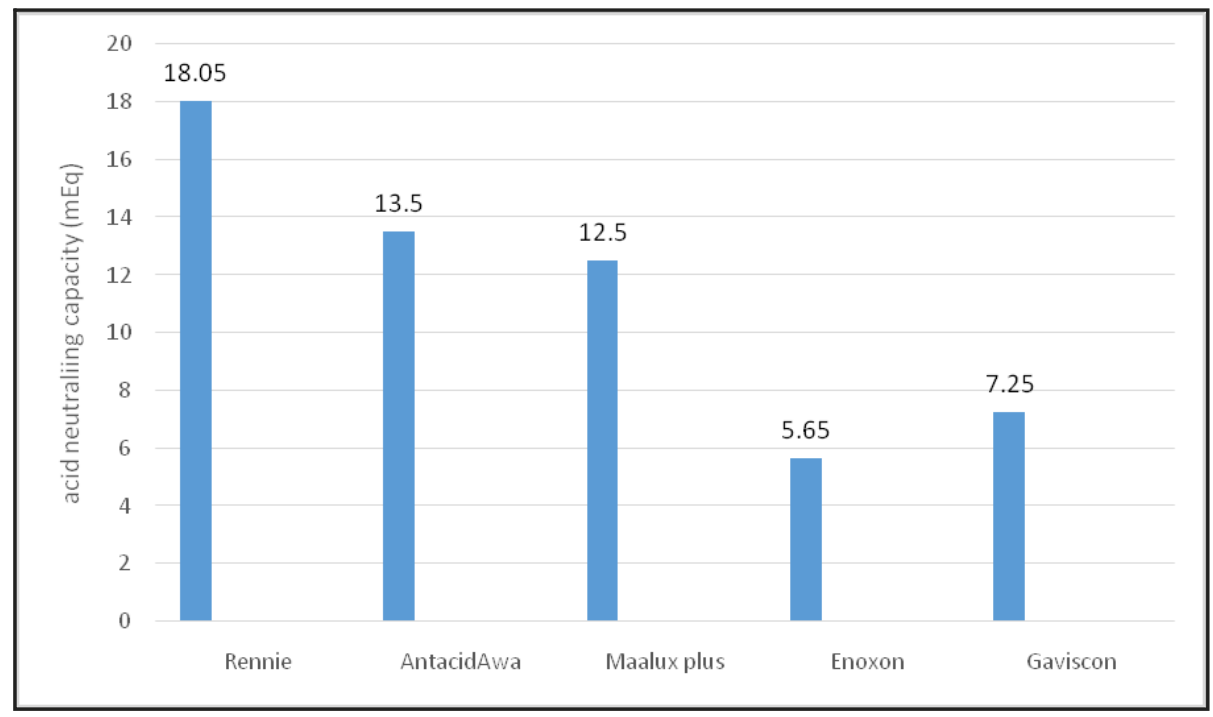

Figure 1: Comparison of acid-neutralizing capacity of the tested antacids. 
The statistical analysis of the Kruskal Wallis test showed that $\mathrm{H}_{\mathrm{c}}$ is 8.33 while $\mathrm{H}$ is 12.9, which means that there is a significant difference between the means of the acid-neutralizing capacity of the different antacids (because $\mathrm{H}>\mathrm{H}_{\mathrm{c}}$ ). The Tukey's Honestly Significance Difference (HSD) is 2.720. The post hoc test showed that the acid-neutralizing capacity of AwaTab® and Maalux®plus are similar and those of Enoxon $®$ and Gaviscon $®$ are also similar. All other antacids showed significantly different acid-neutralizing capacity. Table 3 shows the result of the post hoc test.

\section{Discussion}

Antacids are weak bases that can neutralize the acidity of the stomach. The efficacy of antacids is dependent on their acid-neutralizing capacity. All specified antacids have been tested for their acid-neutralizing capacity according to the procedure in USP pharmacopeia. $^{12}$ Rennie chewable tablet was found to have the highest acid-neutralizing capacity being $18.05 \mathrm{mEq}$. AntacidAwa ${ }^{\circledR}$ tablet and Maalux ${ }^{\circledR}$ plus come next being $13.5 \mathrm{mEq}$ and $12.5 \mathrm{mEq}$, respectively, showing a non-significant difference with each other but with a significant difference with Rennie ${ }^{\circledR}$ chewable tablet and the other antacids. The suspensions tested showed less acid-neutralizing capacity. The acid-neutralizing capacity for
Gaviscon $®$ suspension was $7.25 \mathrm{mEq}$, and that of Enoxon ${ }^{\circledR}$ suspension was only $5.65 \mathrm{mEq}$ with no significant difference. However, all the antacids showed sufficient acid-neutralizing capacity being greater than $5 \mathrm{mEq} .{ }^{11}$ The difference in acidneutralizing capacity is related to the difference in the bases used and the difference in concentration of the bases. Rennie ${ }^{\circledR}$ chewable tablet contains $680 \mathrm{mg}$ of calcium carbonate and a smaller amount (80 mg) of magnesium carbonate. The large amount of calcium carbonate may be responsible for the high acid-neutralizing capacity. Maalux $®$ plus and AntacidAwa $₫$ contain the same amounts of the same antacids (aluminum hydroxide and magnesium hydroxide). Thus, they are showing similar acid-neutralizing capacity. It is shown that the calcium and magnesium carbonate salts present in Renneiß provided higher acid-neutralizing capacity compared to the aluminum and magnesium hydroxides present in Maalux ${ }^{\circledR}$ and AntacidAwa ${ }^{\circledR}$ tablets. The results of acid-neutralizing capacity for Rennie $\AA$, Maalux $®$ plus, and Gaviscone $\AA$ suspension were in consistent with the result found for the same brands of antacid from another work done in Iraq by Al-Mudhafar and colleagues (2016). ${ }^{13}$ The two suspension antacids showed the same acid-neutralizing capacity due to that they contain the same amounts of the same bases per each $10 \mathrm{ml}$ of

Table 3: Post hoc test (Tukey's Honestly Significance Difference (HSD) is 2.720).

Meanacid-neutralizing capacityof Rennie $\AA$ and AwaTab $\AA$ differ: $4.266>2.720$

Mean acid-neutralizing capacityofRennie ${ }^{\circledR}$ and Maalux ${ }^{\circledR}$ plus differ: $4.766>2.720$

Mean acid-neutralizing capacityofRennie ${ }^{\circledR}$ and Enoxon ${ }^{\circledR}$ differ: $12.190>2.720$

Meanacid-neutralizing capacityof Rennie $\AA$ and Gaviscon $\circledast$ differ: $10.433>2.720$

Mean acid-neutralizing capacityofAwaTab ${ }^{\circledR}$ and Maalux ${ }^{\circledR}$ plus are similar: $0.500<2.720$

Mean acid-neutralizing capacityofAwaTab $\AA$ and Enoxon $®$ differ: $7.923>2.720$

Mean acid-neutralizing capacityofAwaTab $\AA$ and Gaviscon $®$ differ: $6.166>2.720$

Mean acid-neutralizing capacityofMaalux® plus and Enoxon® differ: $7.423>2.720$

Mean acid-neutralizing capacityofMaalux® plus and Gaviscon® differ: $5.667>2.720$

Mean acid-neutralizing capacityofEnoxon $\AA$ and Gaviscon $\AA$ are similar: $1.756<2.720$ 
suspension (one dose). They both showed a significantly lower acid-neutralizing capacity compared to the tablets. However, they both contain sodium alginate, which forms a raft. This raft is a mechanical barrier that will prevent acid reflux from the stomach to the esophagus. ${ }^{8}$ Therefore, they may be designed to provide the same clinical effect with lower concentrations of bases to provide less change of $\mathrm{pH}$ of the stomach, thus providing fewer side effects related to the bases and the inactivation of pepsin. The strength of the raft can be improved by the presence of calcium cations, while the bicarbonate is required to make the alginate into a floating foam. Thus, the antacid basic salts that are included with the alginate in Gaviscon ${ }^{\circledR}$ and Enoxon $\circledast$ are not only intended to provide a significant acid-neutralizing capacity but also to improve the efficacy of the raft. ${ }^{14,15}$ Thus, Enoxon ${ }^{\circledR}$ and Gaviscon $₫$ may provide a comparative clinical response for treating gastroesophageal reflex compared to antacids with significantly higher acid-neutralizing capacity despite their low neutralization capacity. This requires more investigation.

\section{Conclusion}

Acid-neutralizing capacity is an important factor for determining the potency of antacids to provide symptomatic relief from dyspepsia. All antacids showed significant acid-neutralizing capacity. However, Rennie ${ }^{\circledR}$ chewable tablet displayed the highest acid-neutralizing capacity. Thus, it may have a better effect on increasing the $\mathrm{pH}$ of the stomach and may show more effect in the treatment of dyspepsia symptoms. The suspensions containing sodium alginate showed lower acidneutralizing capacity, but the additional effect of the raft may compensate for that.

\section{Competing interests}

The authors declare no competing interests.

\section{References}

1. Brown $M$, Sharma $P$, Mir $F$, Bennett $P$. Gastrointestinal system. In: Bansi D, Hateley C, Louis J. Clinical Pharmacology. $12^{\text {th }}$ ed. London: Elsevier; 2019. P. 562-94.

2. Abdu K, Abbagana M, Evaluation of neutralizing capacity of different commercial brands of antacid tablets. Chem Search J 2015; 6(2):32-4.

3. Smith G, Arson K. Oxford text book of clinical pharmacology and drug therapy. $3^{\text {rd }}$ ed. New York: Oxford; 2002. P. 276-7.

4. Sathoskar S, Bhandarkar D, Rege N. Pharmacology and pharmacotherapeutics. $21^{\text {st }}$ ed. Mumbai: Popular Prakashan; 2009. P. 612-6.

5. Tripathi D. Essentials of medical pharmacology. $6^{\text {th }}$ ed. New Delhi: Jeyapee; 2008. P. 627-38.

6. Jagadesh K, Chidananda K. Study of acid-neutralizing capacity of various antacid formulations. AJPTI 2015; 03(12):113-20.

7. Bhoir S, Bhagwath M. Comparison of seven oxethazine containing antacids available in Indian market. JAPI 2013; 61:400-3.

8. Jakaria $M$, Zaman $R$, Parvez $M$, Islam $M$, Haque A, Abu Sayeed $M$, et al. Comparative study among the different formulation of antacid tablets by using acid-base neutralization reaction. Global J Pharmacol 2015; 9(3):278-81.

9. Grinshpan D, Nevar T, Savitskaya T, Boiko A, Kapralov N, Sholomitskaya I. Comparison of acid-neutralizing properties of anti-acid preparations of various compositions. Pharm Chem J 2008; 42:400-4.

10. Jacob S, Shirwaikar A, Anoop S, Khaled R, Imtiaz M, Nair A. Acid neutralization capacity and cost effectiveness of antacids sold in various retail pharmacies in the United Arab Emirates. Hamdan Med J 2016; 9:137-46.

11. Alalor C, Avbunudiogba J, Builders F, Okpara L. Evaluation of the acid-neutralizing capacity of Some Commercially Available Brands of Antacid Tablets in Nigeria. East Afr Med J 2019; 2(1):126.

12. USP31-NF26, acid-neutralizing capacity, 301. (accessed September 5, 2019, at http://www.uspbpep.com/usp31/v31261/ usp31nf26s1_c301.asp).

13. Al-Mudhafar $\bar{M}$, Abdulhadi S, Talib B. Evaluation of commercial antacid tablets in Iraq. Der Pharma Chemica 2016; 8(19):283-8.

14. Mandel K, Daggy $P$, Brodie $D$, Jacoby $H$. Alginate-raft formulations in the treatment of heartburn and acid reflux. Aliment Pharmacol Ther 2000; 14:669-90.

15. Prajapati S, Mehta A, Modhia I, Patel C. Formulation and optimisation of raft-forming chewable tablets containing $\mathrm{H} 2$ antagonist. Int J Pharm Investig 2012; 2(4):176-82. 